\title{
EVALUASI DAN STATUS PERKEMBANGAN USAHA BUDIDAYA IKAN DALAM KERAMBA JARING APUNG DI DANAU MANINJAU, SUMATERA BARAT
}

\author{
Rasidi, Erlania, dan Anjang Bangun Prasetio \\ Pusat Riset Perikanan Budidaya \\ Jl. Ragunan 20, Pasar Minggu, Jakarta Selatan 12540 \\ E-mail: rasidi@ cria.indosat.net.id
}

\section{ABSTRAK}

Kegiatan budidaya ikan dalam Keramba Jaring Apung (KJA) di Danau Maninjau, Sumatera Barat sudah berkembang pesat. Kegiatan penelitian telah dilakukan pada tahun 2009 dengan metode Parcipatory Rural Apraisal (PRA). Tujuan dari kegiatan ini adalah untuk mengevaluasi dan mengetahui status perkembangan budidaya ikan yang ada di Danau Maninjau dilihat dari aspek teknis budidaya dan kelayakan ekonomis usaha budidayanya. Berdasarkan evaluasi teknis budidaya, sebagian besar ikan yang dipelihara adalah ikan nila dengan sistem KJA tunggal, pemberian pakan dengan sistem pompa, dan nilai FCR rata-rata pada budidaya ikan nila sebesar 1,61. Manajemen budidaya yang diterapkan oleh pembudidaya relatif masih sederhana, yang terlihat dari penempatan KJA yang sebagian besar di pinggir danau dan pemberian pakan yang belum sesuai cara budidaya yang baik dan benar (CBIB). Berdasarkan analisis kelayakan usaha, budidaya ikan dalam KJA tunggal di Danau Maninjau pada saat dilakukan penelitian ini, masih tergolong layak untuk dilakukan. Tetapi tidak disarankan untuk pengembangan kegiatan budidaya dengan sistem KJA tunggal, karena pakan yang terbuang ke perai ran relatif lebih banyak sehingga tidak ramah lingkungan. Alternatif kebijakan yang perlu diterapkan oleh pemerintah setempat dalam pengeIolaan perikanan budidaya di Danau Maninjau adalah kebijakan yang mengarah kepada penerapan manajemen budidaya yang sesuai kaidah CBIB, pengaturan kembali tata letak KJA, untuk permodalan diperlukan peran serta pemerintah daerah untuk pembentukan koperasi pembudidaya sehingga dapat membantu permodalan dengan memberikan kredit dengan bunga rendah. Opsiopsi kebijakan tersebut kiranya dapat diterapkan untuk mendukung pengembangan dan keberlanjutan kegiatan budidaya ikan di Danau Maninjau.

KATAKUNCl: evaluasi, status perkembangan, budidaya ikan, KJA

\section{PENDAHULUAN}

Danau Maninjau merupakan salah satu danau yang memiliki peranan penting di Sumatera Barat, terkait dengan salah satu fungsinya, yaitu sebagai sarana Pembangkit Listrik Tenaga Air (PLTA). Danau Maninjau yang memiliki luas 9.950 ha, secara administratif termasuk ke dalam wilayah Kecamatan Tanjung Raya Kabupaten Agam Provinsi Sumatra Barat, di mana lokasi tersebut berjarak $\pm 105 \mathrm{~km}$ dari ibu kota provinsi. Secara geografis wilayah ini terletak pada ketinggian $461,5 \mathrm{~m}$ di atas permukaan laut. Dilihat dari proses terbentuknya, Danau Maninjau merupakan danau tektonik-vulkanik (LIPI, 2007). Pemanfaatan Danau Maninjau selain untuk PLTA adalah untuk kegiatan pariwisata, konservasi, dan perikanan (penangkapan dan budidaya). Kegiatan budidaya ikan dengan KJA di Danau Maninjau mengalami perkembangan yang pesat. Peningkatan jumlah KJA yang tidak terkontrol dan kebiasaan budidaya yang kurang baik, untuk jangka waktu yang lama dikhawatirkan akan menimbulkan dampak negatif, baik terhadap lingkungan perairan danau itu sendiri maupun bagi kelangsungan usaha budidaya. Selain itu, permasalahan yang sering dihadapi oleh pembudidaya di Danau Maninjau adalah kematian massal ikan yang terjadi hampir setiap tahun, yang diduga akibat fenomena alam yaitu up-welling (umbalan).

Penelitian ini bertujuan untuk menganalisis status perkembangan usaha budidaya ikan dalam KJA berdasarkan kajian teknis dan kelayakan finansialnya. Kajian aspek teknis dilakukan untuk mengetahui status perkembangan budidaya dan kondisi secara umum, sedangkan kajian finansial untuk melihat apakah usaha pembesaran ikan nila yang dipelihara dengan sistem KJA tunggal masih memberikan keuntungan dan dapat dipertimbangkan sebagai suatu usaha yang berkelanjutan. Dari hasil analisis yang dilakukan, diharapkan dapat memberikan masukan untuk menentukan arah kebijakan dari pemerintah setempat dalam rangka mengoptimalkan hasil produksi perikanan budidaya di Danau Maninjau. 


\section{METODE}

Penelitian telah dilakukan pada bulan SeptemberOktober 2009 di Danau Maninjau, Sumatera Barat. Metode yang digunakan dalam penelitian ini adalah Parcipatory Rural Apraisal (PRA). Pengumpulan data primer dilakukan melalui wawancara langsung dengan 35 orang pembudidaya, Dinas Perikanan setempat, Sekda Kabupaten Agam, penyuluh, serta tokoh-tokoh masyarakat. Data primer merupakan data yang dikumpulkan di lapangan terutama yang berhubungan dengan pemanfaatan dan pengelolaan budidaya ikan di KJA, teknis produksi budidaya ikan di KJA, perkembangan usaha, pemasaran, dan kelembagaan. Sedangkan data sekunder diambil dari Dinas Perikanan, lembaga/organisasi pembudidaya, serta studi literatur yang berkaitan dengan budidaya KJA. Dari data yang diperoleh dilakukan analisis secara deskriptif.

\section{HASIL DAN BAHASAN}

\section{Manajemen Budidaya}

Secara umum manajemen budidaya yang ada di Danau Maninjau dapat dipaparkan sebagai berikut; proses budidaya diawali dari persiapan KJA, keramba diapungkan menggunakan rakit yang terbuat dari kerangka bambu, kayu atau besi tergantung dari skala usahanya. Benih berasal dari penggelondongan yang ada di sekitar danau (Gambar 1).

Berdasarkan hasil wawancara dengan pembudidaya, sebagian besar kegiatan budidaya ikan nila yang sudah berkembang di Danau Maninjau menggunakan sistem KJA tunggal. Berdasarkan analisis data hasil wawancara selama penelitian disajikan pada Tabel 1 , sistem budidaya KJA di Danau Maninjau masih relatif sederhana, usaha
Tabel 1. Kondisi budidaya ikan nila pada KJA tunggal

\begin{tabular}{lc}
\hline \multicolumn{1}{c}{ Uraian } & Kisaran \\
\hline Ukuran KJA & $5 \mathrm{~m} \times 5 \mathrm{~m} \times 3 \mathrm{~m}$ \\
Jumlah tebar & $5.000-20.000$ ekor/petak \\
& $(50-250 \mathrm{~kg} /$ petak $)$ \\
Hasil panen & $1.112 \mathrm{~kg} / \mathrm{siklus} /$ petak \\
Lama pemeliharaan & 153 hari \\
Penggunaan pakan & $1.424 \mathrm{~kg} / \mathrm{siklus} /$ petak \\
Sintasan (\%) & 57 \\
Laju pertumbuhan individu & $1,38 \mathrm{~g} / \mathrm{hari}$ \\
FCR & 1,61 \\
\hline
\end{tabular}

pembesaran menggunakan KJA yang terbuat dari polyetilen, ukuran KJA sistem tunggal dengan ukuran bervariasi rata-rata $5 \mathrm{~m} \times 5 \mathrm{~m} \times 3 \mathrm{~m}$ dengan kedalaman 3$5 \mathrm{~m}$. Sebagian besar ikan yang dipelihara ikan nila. Pemberian pakan diberikan dengan sistem pompa dengan frekuensi 3 kali dalam sehari. Padat tebar 5.000-20.000 ekor/petak dengan hasil panen sebesar $1.112 \mathrm{~kg} / \mathrm{siklus}$. Budidaya ikan di Danau Maninjau ini sangat rentan kematian, terlihat dari nilai sintasan rata-rata yang sangat tinggi sebesar $57 \%$

Umumnya komoditas yang dibudidayakan adalah ikan nila dengan sistem KJA tunggal secara monokultur. Jarak antar KJA relatif berdekatan (Gambar 2) dan penempatan KJA sebagian besar di pinggir danau (Gambar 3), dengan tujuan untuk memudahkan pembudidaya dalam melakukan pengawasan dan pengelolaan KJA sehari-hari. Tata letak dan penempatan KJA yang seperti ini dapat menimbulkan dampak negatif terhadap kegiatan budidaya. Penempatan KJA di pinggir danau menyebabkan ikan-ikan budidaya sangat rentan terhadap risiko kematian massal jika terjadi

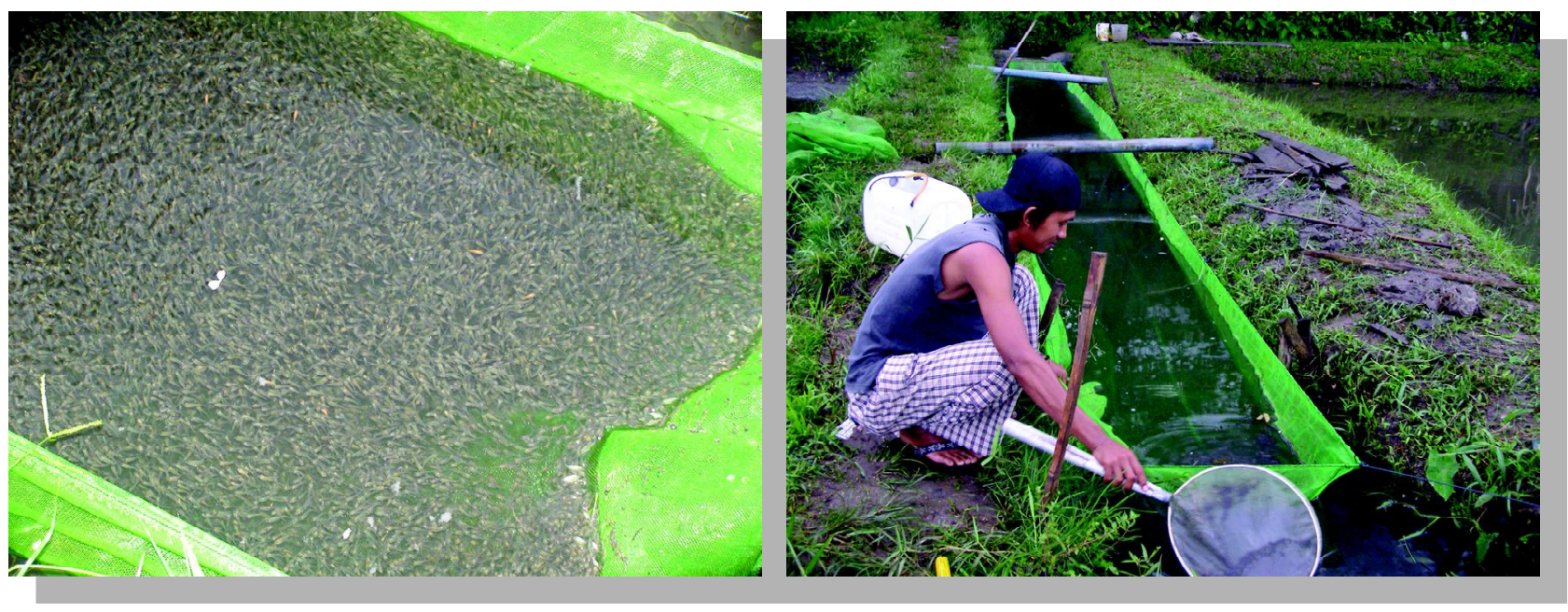

Gambar 1. Aktivitas pengelondongan yang ada di sekitar Danau Maninjau 


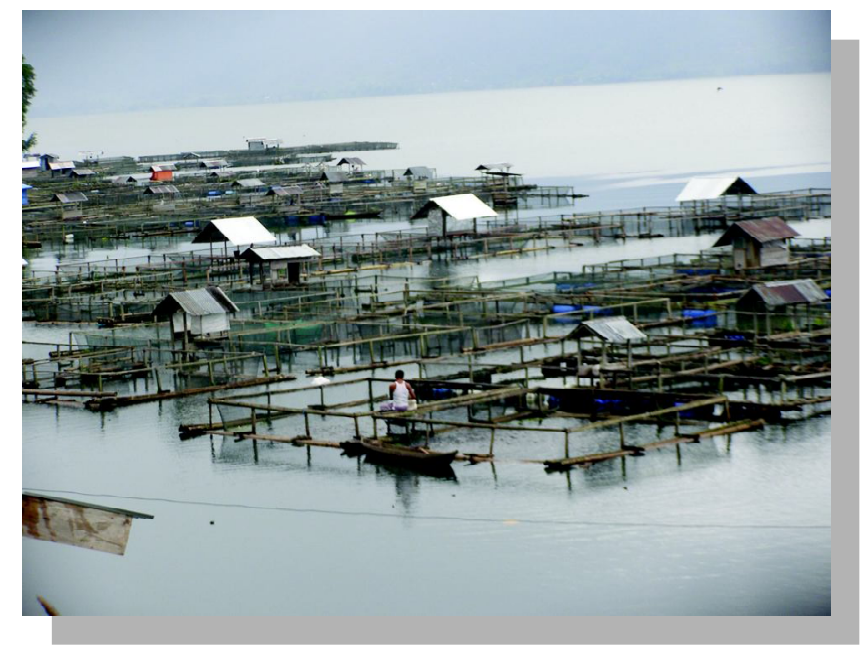

Gambar 2. Kondisi KJA di Danau Maninjau

up-welling. Hal ini disebabkan karena kurangnya sirkulasi air, sehingga limbah budidaya terakumulasi di dasar perairan di lokasi KJA itu sendiri. Akibatnya pada saat terjadi pembalikan massa air akibat up-welling akan menyebabkan terangkatnya senyawa-senyawa toksik yang dihasilkan oleh proses dekomposisi anaerob dari limbah organik dari dasar ke permukaan perairan, yang pada akhirnya menyebabkan kematian massal ikan-ikan budidaya (Gambar 4).

Pengembangan teknologi budidaya pada KJA di perairan danau telah memberikan dampak positif terhadap peningkatan produksi ikan, konsumsi ikan, peluang usaha, kesempatan kerja, dan peningkatan pendapatan. Namun dikarenakan sebagian besar pembudidaya melakukan manajemen budidaya yang belum tepat kegiatan KJA dapat mengganggu pelestarian sumberdaya danau terutama

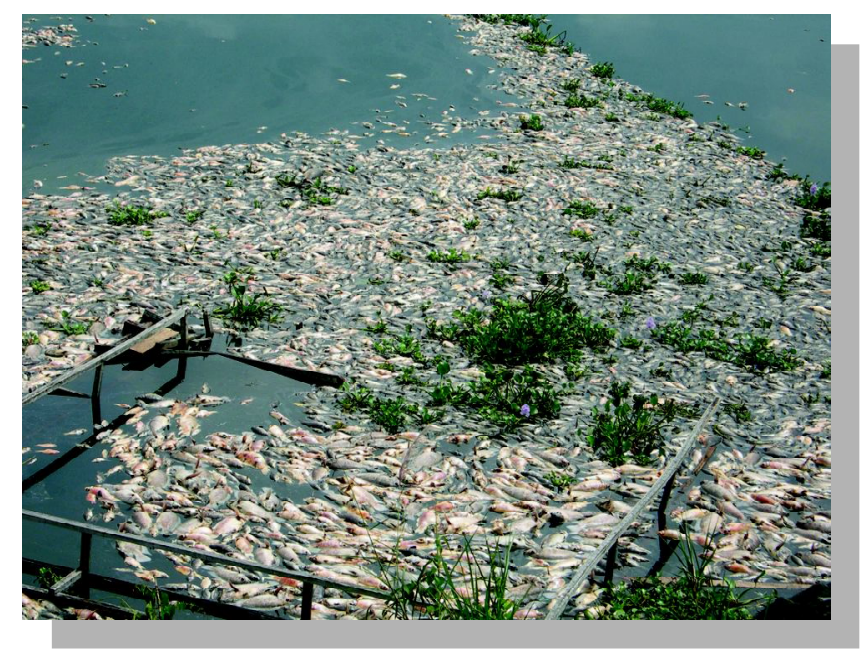

Gambar 4. Kematian massal ikan yang sering terjadi di Danau Maninjau

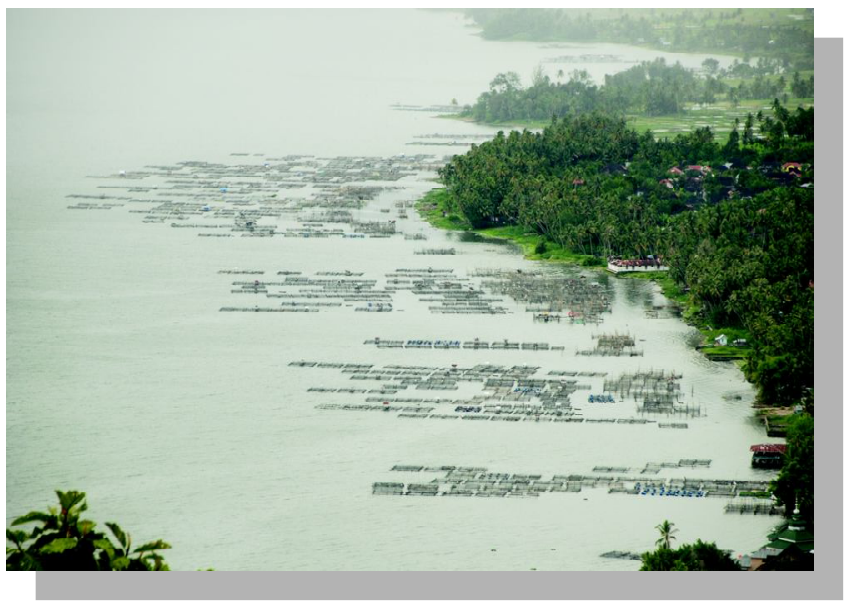

Gambar 3. Tata letak KJA di Danau Maninjau yang terlalu ke pinggir danau

penurunan kualitas perairan maupun usaha perikanan itu sendiri. Budidaya KJA di Danau Maninjau dimulai pada tahun 1990 (Noor, 2002). Dari data yang ada hingga 2001 jumlah kerambajaring apung (cage culture) sebanyak 3.500 unit. Akibat aktivitas tersebut dihasilkan limbah yang berasal dari pakan ikan sebanyak 292,88 ton/tahun; nitrogen 146,68 ton/tahun; dan urea 310,0 ton/tahun (Syandri et al., 2000). Sampai akhir tahun 2006, terdapat 8.955 unit KJA yang beroperasi di perairan Danau Maninjau (Syandri, 2006). Menurut hasil survai terakhir, jumlah unit KJA sampai dengan bulan Maret 2008 tercatat berjumlah 15.123 unit (Putra, 2009). Perkembangan budidaya KJA dengan pola budidayanya yang tidak ramah lingkungan telah menurunkan kualitas perairan Danau Maninjau. Hal ini di antaranya disebabkan oleh buangan 'bangkai' keramba yang tidak terpakai yang sudah tidak beroperasi lagi seperti drum bekas, bambu, dan plastik serta aplikasi pakan yang berlebihan yang mengendap di dasar danau dan menjadi salah satu faktor penyebab kematian massal ikan dan kegagalan usaha (Sudjana dalam Krismono et al., 2006).

Dengan melihat kejadian kematian massal yang pernah terjadi pada tahun 1997 sebanyak 950 ton ikan dengan kerugian mencapai 2,7 milyar (Syandri, 2004) dan kematian massal ikan di Danau Maninjau pernah terjadi pada Januari 2009 lalu dengan kerugian sebanyak 7 ribu ton ikan keramba mati dalam sepekan yang menyebabkan kerugian petani keramba hingga Rp 80 miliar (www.tempo.interaktif, 2010). Salah satu alternatif untuk menghindari kematian massal tersebut, yang perlu dilakukan di antaranya yaitu pengelolaan budidaya yang sesuai dengan standar budidaya yang baik dan benar. Antara lain pemberian pakan yang sesuai dosis, pengaturan kembali tata letak KJA, dan pengembangan sistem KJA 
ganda di Danau Maninjau. Teknologi budidaya KJA dua lapis ini dikenal dengan sebutan sistem KJA ganda dapat menghemat biaya pakan karena pada sistem ini menggunakan dua kantung jaring yakni di lapisan atas dan lapisan bawah, pada kedua jaring ini dilakukan penebaran ikan dengan jenis yang berbeda. Teknologi jaring ganda ini dikembangkan karena pada budidaya KJA yang dilakukan di waduk yang berada di Jawa Barat teridentifikasi bahwa pakan yang terbuang ke perairan mencapai 30\%"40\%(Kartamiharja, 1988). Teknologi KJA ganda ini selain digunakan untuk memanfaatkan pakan yang terbuang ke perairan, juga bertujuan untuk menekan pencemaran limbah organik yang berasal dari sisa pakan tersebut.

\section{Analisis Ekonomi}

Untuk melihat kelayakan usaha budidaya ikan nila dalam KJA dilakukan analisis usaha. Anal isis usaha yang disajikan diambil dari 35 responden yang mewakili 5 kelompok budidaya yang menerapkan KJA tunggal di Danau Maninjau. Analisis usaha budidaya ikan nila dalam KJA tunggal untuk 1 siklus budidaya selama 4 bulan pemeliharaan.

Ditinjau dari segi ekonomi usaha budidaya ikan dalam KJA tunggal memberikan keuntungan total usaha sebesar Rp 4.473.920,-/periode usaha selama 4 bulan (Tabel 2). Investasi usaha yang diperlukan untuk budidaya KJA tunggal memerlukan dana sebesar Rp 26.096.700,-untuk mengusahakan keramba jaring apung (2 petak) selama 4 bulan. Besaran dana tersebut merupakan dana yang cukup besar, mengingat mata pencaharian pembudidaya sebagian besar sebagai buruh KJA. Sedangkan biaya produksi yang ada sebesar Rp 22.436.480,-. Biaya produksi tersebut terdiri atas biaya tetap dan biaya variabel. Biaya tetap terdiri atas biaya penyusutan/rehab rakit, pemeliharaan $\mathrm{KJA}$, dan bunga investasi. Sedangkan biaya variabel terdiri atas benih, pakan, dan tenaga kerja. Dari Tabel 2 terlihat pula 73,62\%merupakan modal kerja yang berfungsi untuk pembelian pakan untuk pakan ikan yang dipelihara. Di sisi lain bunga investasi selama 4 bulan mencapai Rp 1.739.780,-.

Rata-rata harga ikan nila Rp 12.100,- dengan harga tersebut, penerimaan hasil penjualan ikan nila untuk satu kali produksi sebesar Rp 26.910.400,-. Jika dibandingkan dengan biaya produksi yang dikeluarkan, maka usaha budidaya pembesaran dalam KJA tunggal menghasilkan keuntungan sebesar Rp 4.473.920,-. Dengan asumsi bahwa setiap tahun usaha budidaya dengan sistem jaring tunggal adalah tetap, maka dihasilkan payback period (waktu pengembalian modal) sebesar 5,14 siklus pemeliharaan (1,7 tahun).

\section{Pemasaran}

Proses pemasaran diawali dari pemanenan di tingkat pembudidaya dan dibeli oleh pedagang pengumpul lokal, kemudian dikirim ke daerah pemasaran seperti Padang, Pekanbaru, Sawahlunto, Solok, dan Jambi. Menurut informasi dari tenaga penyuluh, jumlah pedagang pengepul di sekitar danau sebanyak 7 orang. Ukuran panen tergantung permintaan pasar. Harga jual dari pembudidaya untuk ikan nila rata-rata sebesar $\mathrm{Rp} 11.000,--\mathrm{Rp} 12.100,-/ \mathrm{kg}$.

Tabel 2. Struktur biaya produksi usaha budidaya ikan dalam sistem KJA tunggal di Danau Maninjau

\begin{tabular}{lrc}
\hline \multicolumn{1}{c}{ Uraian } & KJA tunggal (Rp) & Persentase (\%) \\
\hline A Investasi & 26.096 .700 & 100 \\
Konstruksi KJA tunggal (rakit pengapung, drum, jaring, rumah jaga (untuk 2 & 6.000 .000 & 22,99 \\
petak) & 20.096 .700 & 77,01 \\
Modal kerja & 2.339 .780 & 10,43 \\
B Biaya tetap & 600.000 & 2,67 \\
Penyusutan/rehab rakit, pelampung, KJA (10 thn) & 1.739 .780 & 7,75 \\
Bunga investasi (20\%per tahun) & 20.096 .700 & 89,57 \\
C Biaya variabel & 1.578 .300 & 7,03 \\
Benih ikan nila (5.261 ekor x 2 petak x Rp 150,-lekor x 1 siklus) & 16.518 .400 & 73,62 \\
Pakan ikan nila (1.424 kg x 2 petak x Rp 5.800,- x 1 siklus) & 2.000 .000 & 8,91 \\
Tenaga kerja (1 orang x 4 bulan x Rp 500.000,-) & 22.436 .480 & 100 \\
D Total biaya produksi (B+C) & 26.910 .400 & 100 \\
E Produksi ikan nila (1.112 kg x 2 petak x Rp 12.100,-) & 26.910 .400 & 100 \\
F Nilai produksi total & 4.473 .920 & 100 \\
G Keuntungan usaha total (F-D) & & \\
\hline
\end{tabular}


Tabel 3. Analisis usaha budidaya ikan dalam sistem KJA tunggal

\begin{tabular}{lc}
\hline a Pendapatan & \\
$\quad$ (Bobot ikan yang dipanen x jumlah siklus x jumlah unit x harga/kg) & 26.910 .400 \\
b Cash flow (arus kas) & \\
$\quad$ Keuntungan + penyusutan & 5.073 .920 \\
c Rentabilitas ekonomi & \\
$\quad$ (Keuntungan/total investasi) x 100\% & 17,14 \\
d Pay back periode & 5,14 \\
$\quad$ Total biaya investasi/cash flow & \\
e Break event point (BEP) & $9.240 .885,29$ \\
$\quad$ Biaya tetap / (1-biaya variabel/biaya pendapatan) & \\
f BEP volume (kg) & 1.854 \\
$\quad$ Total biaya produksi/harga jual per kg & \\
g BEP harga (Rp/kg) & 10.088 \\
$\quad$ Total biaya produksi/produksi & \\
\hline
\end{tabular}

Berdasarkan kompilasi data dan informasi yang diperoleh dalam studi yang telah dilakukan, beberapa permasalahan yang menghambat usaha budidaya ikan di KJA antara lain masalah permodalan. Sebagai contoh kasus di atas untuk melakukan aktivitas budidaya dalam KJA diperlukan investasi sebesar Rp 26.096.700,-, nilai investasi ini tidak dapat diselesaikan oleh pembudidaya sendiri secara perorangan dengan segala keterbatasannya untuk akses ke perbankan.

Permasalahan kedua yaitu permasalahan klasik pada budidaya yaitu harga pakan yang cukup mahal berkisar Rp 280.000,--Rp 295.000,- per karung, mengingat mahalnya harga pakan dan banyaknya kebutuhan operasional pakan maka diperlukan bahan baku lokal untuk menekan biaya produksi budidaya ikan nila.

Dilihat dari kelembagaan pembudidaya sudah terbentuk kelompok-kelompok pembudidaya (pokdakan) yang sangat membantu dalam mengatasi masalah budidaya dan pendanaannya. Kelompok pembudidaya ini sangat membantu dalam memperoleh kucuran dana jika ada program paket bantuan benih, pakan dari pemerintah daerah. Dari hasil wawancara, belum ada lembaga keuangan seperti koperasi simpan pinjam yang akan membantu proses peminjaman ke anggotanya. Selama ini pembudidaya meminjam ke bank dengan jaminan surat tanah atau kendaraan yang dimiliki pembudidaya.

\section{KESIMPULAN DAN SARAN}

\section{Kesimpulan}

Berdasarkan hasil dan bahasan dapat ditarik kesimpulan sebagai berikut:
1. Berdasarkan kajian evaluasi teknis yang telah dilakukan, sebagian besar ikan yang dibudidayakan adalah ikan nila dengan sistem KJA tunggal dengan manajemen budidaya yang masih sederhana. Penempatan KJA juga masih sangat rapat dan terletak di pinggir danau, untuk itu, perlu pemindahan dan pengaturan kembali tata letak KJA yang ada di Danau Maninjau

2. Berdasarkan anal isis kelayakan usaha, budidaya ikan dalam KJA tunggal di Danau Maninjau pada saat dilakukan penelitian ini masih tergolong masih layak untuk diusahakan, tetapi dengan risiko tinggi terhadap kematian ikan. Akibatnya pembudidaya banyak yang tidak dapat lagi melanjutkan usahanya.

\section{Saran}

Permasalahan yang dihadapi oleh pembudidaya antara lain permodalan dan harga pakan yang tinggi. Untuk aspek permodalan diperlukan peran serta pemerintah daerah untuk pembentukan koperasi pembudidaya sehingga diharapkan dapat untuk meminjamkan dananya dengan bunga rendah. Sedangkan harga pakan yang tinggi, diperlukan penghematan pemberian pakan dengan dosis yang telah ditentukan melalui perhitungan yang cermat. Selain itu, perlu dicari alternatif pakan yang murah dengan cara menggali penggunaan potensi bahan baku lokal.

\section{DAFTAR ACUAN}

Anonim. 1997. Laporan hasil Sistim Usaha Perikanan. Inlitkanwar Jatiluhur.

Anonim. 2001. Permasalahan Danau Maninjau dan Pendekatan Permasalahannya. Laporan Proyek 
Pengembangan dan Peningkatan kemampuan Teknologi, Pusat Limnologi LIPI, Cibinong.

Harjamulia, A., Suhenda, N., \& Krismono. 1991. Budidaya Ikan Air Tawar dalam Keramba Jaring Apung Mini. Puslibangkan Jakarta, $23 \mathrm{hlm}$.

Krismono, Nurfiarini, A., \& Prihadi, T.H. 2006. Analisis Kebijakan Pengelolaan Perbenihan dan pakan dalam mendukung optimalisasi Budidaya ikan dalam KJA (Studi kasus pada kegiatan budidaya ikan dalam KJA di Waduk Saguling, Cirata, dan Jatiluhur. Analisis Kebijakan Perikanan Budidaya. Pusat Riset Perikanan Budidaya, Jakarta.

Lembaga IImu Pengetahuan Indonesia (LIPI). 2007. Program Penyehatan Danau Maninjau dan Pemberdayaan Masyarakat di Sekitar Danau. Pusat Penelitian Limnologi - LIPI. Cibinong, $38 \mathrm{hlm}$.

Millamena, O.M. et al. 2002. Nutrition of Tropical Aquaculture.SEAFDEC, Philipines.
Noor, M. 2002. Bioeconomic of the culture for common carp in floating net cage in the Maninjau Lake West Sumatera. J. Ekonomi Pembanguinan, 7(1): 21-31.

Pratiwi, E., Supriyono, E.W., Suhenda, N., \& Kusmini, I.I. 1998. Pemanfaatan Sisa Pakan Ikan Mas oleh Ikan Nila dalam KJA Ganda yang Ramah Lingkungan. Pusat Penelitian dan Pengembangan Perikanan, Jakarta, J. Pen. Perik. Indonesia, IV(2): 41-48.

Putra, A.D. 2009. Rencana Kerja Penyuluh 2009. Dinas Kelautan dan Perikanan Agam, $18 \mathrm{hlm}$.

Gustiano, R., Nasution, Z., \& Suryanti, Y. 2006. Analisis Kebijakan Usaha Budidaya Bandeng Air Tawar di Keramba Jaring Apung. Pusat Riset Perikanan Budidaya Jakarta, M edia Akuakultur, 1(1): 33"39.

Lukman, T. \& Meutia, A.A. 2005. Introduksi Keramba Jaring Apung Berlapis sebagai alternatif Pemeliharaan Ikan dalam Karamba Ramah Lingkungan. Puslit Limnologi LIPI Cibinong, Limnotek., XII(2): 59-65. 